\title{
Estrogen receptor beta and truncated variants enhance the expression of transfected MMP-1 promoter constructs in response to specific mechanical loading
}

\author{
John D Thaler ${ }^{1}$, Yamini Achari ${ }^{1}$, Ting Lu', Nigel G Shrive ${ }^{1,2}$ and David A Hart ${ }^{1 *}$
}

\begin{abstract}
Background: Joint diseases such as osteoarthritis (OA) predominantly afflict post-menopausal women, suggesting a pertinent role for female hormones. Estrogen receptor beta $(E R-\beta)$ has been detected in connective tissues of the knee joint suggesting that these tissues are responsive to the hormone estrogen. Matrix metalloproteinase-1 (MMP-1) activity contributes to cartilage degradation, a key factor leading to OA development in synovial joints. Two polymorphic forms of MMP-1 exist due to a deletion/insertion of the guanine residue in the promoter, and the $2 \mathrm{G}$ allelic variant of MMP-1 exhibits more activity than the $1 \mathrm{G}$ allele. Previous studies have demonstrated that the polymorphic forms of the human MMP-1 are influenced by the modulating effects of estrogen receptor isoforms. In addition to hormonal influences, physiological factors such as altered mechanical loading are also contributory features of $\mathrm{OA}$. In the present study, the combined influence of biomechanical and hormonal variables on the activity of MMP-1 isoforms was evaluated. We hypothesized that the combined effects of ER- $\beta$ and sheer stress will differentially activate the two allelic forms of MMP-1 in a hormone-independent manner.

Methods: HIG-82 synoviocytes were transiently transfected with $1 \mathrm{G}$ or $2 \mathrm{G}$ alleles ( \pm ) ER- $\beta$ and subjected to either shear or equibiaxial stress. Next, $1 \mathrm{G} / 2 \mathrm{G}$ promoter activity was measured to determine the combined influence of physiological stimuli. Truncated ER- $\beta$ constructs were used to determine the importance of different domains of ER- $\beta$ on $1 G / 2 G$ activation.

Results: The $2 \mathrm{G}$ allele exhibited a constitutively higher activity than the $1 \mathrm{G}$ allele, which was further increased when the transfected cells were subject to shear stress, but not equibiaxial stress. Moreover, the combination of ER- $\beta$ and shear stress further increased the activity levels of the $1 \mathrm{G} / 2 \mathrm{G}$ allelic variants. Additionally, select AF-2 truncated ER- $\beta$ variants led to increased activity levels for the $2 \mathrm{G}$ allele, indicating the AF-1 domain was likely involved in the response to mechanical stimulation.
\end{abstract}

Conclusions: These results suggest that the $1 \mathrm{G} / 2 \mathrm{G}$ alleles of MMP-1 are influenced by specific mechanical stimuli like shear stress, as well as the ER- $\beta$ receptor. These findings contribute to the potential allelic involvement in connective tissue diseases such as $\mathrm{OA}$ in females compared to males.

Keywords: MMP-1, 1G variant, 2 G variant, ER- $\beta$, Truncated ER-beta, Shear stress and HIG-82 cells

\footnotetext{
* Correspondence: hartd@ucalgary.ca

${ }^{1}$ McCaig Institute for Bone and Joint Health, University of Calgary, 3330

Hospital Drive NW, Calgary, AB T2N 4 N1, Canada

Full list of author information is available at the end of the article
} 


\section{Background}

Gender differences play a pivotal role not only in the development of chronic diseases such as osteoarthritis and osteoporosis but also in the incidence of knee injuries. It is well recognized that females experience a higher incidence of joint injuries such as tearing of the anterior cruciate ligament of the knee joint than males [1]. Several studies investigating the functioning of the knee have reported alterations in knee laxity and related factors during the menstrual cycle [2,3]. Studies have implicated hormones and their receptors in the regulation of connective tissues. Evidence for the presence of estrogen and progesterone receptors in the connective tissues of the knee joint has been provided [4,5], suggesting that these tissues are responsive to hormones which in turn may influence connective tissue turnover. The increased prevalence of osteoarthritis (OA) in women suggests that to understand the sex differences in the development of $\mathrm{OA}$, it is important to examine sex hormone mechanisms in cells from knee tissues [6].

Members of the family of matrix metalloproteinases (MMPs) have been shown to be involved in the catabolic degradation of the connective tissues in the knee joint [7-10] and others. One of the MMPs that has been implicated to play a role in the injured connective tissues and degenerative $\mathrm{OA}$ is matrix metalloproteinase-1 (MMP-1). MMP-1 is the most ubiquitously expressed collagenase, with most normal connective tissue cells expressing low constitutive levels $[11,12]$. However, inflammatory cytokines such as interleukin-1 beta (IL-1 $\beta$ ) and tumor necrosis factor-alpha (TNF- $\alpha$ ) can stimulate the production of this proteinase. The response of the MMP-1 gene to different stimuli is regulated by the promoter elements in the gene. The transcription factor binding sites located in the promoter region of the MMP-1 gene are essential for understanding the control of gene expression in response to different stimuli. A single nucleotide polymorphism (SNP) has been identified in the promoter of the MMP-1 gene which strongly impacts the response of this gene to different stimuli $[13,14]$. This SNP in the promoter of MMP-1 exists at position $-1,607 \mathrm{bp}$, where an additional $\mathrm{G}$ residue creates an Ets binding site (5'GGAT3' compared to 5' GAT3') adjacent to an AP-1 site at $-1,602$ bp. The addition of this guanine $(G)$ residue creates a $2 G$ allele which displays greater transcriptional activity than the $1 G$ allele [12]. The presence of a MMP-1 1 G/2G polymorphism in the promoter region of the MMP-1 gene is positively correlated with an increased risk for developing various types of cancer such as lung or ovarian cancer [15]. Furthermore, a recent study has also demonstrated that the $1 \mathrm{G} / 2 \mathrm{G}$ polymorphism of MMP-1 might be a risk factor for knee osteoarthritis susceptibility in the Greek population [16]. This is in contrast to a separate study which demonstrated an association between the 1G allele and knee OA in a Turkish population [17] and, furthermore, is possibly contrary to expectations that the $2 \mathrm{G}$ allele is associated with higher levels of MMP-1 and hence would be associated with development and progression of OA.

Although it is well recognized that the 2G SNP of MMP-1 leads to a higher constitutive activity than the $1 \mathrm{G}$ allelic form, the activity of this gene is further influenced by other modulators such retinoids, glucocorticoids, growth factors, sex hormones and their receptors, and mechanical stress. In a previous report, Achari et al. [18] have examined the interaction between estrogen, estrogen receptors (ERs), and the MMP-1 promoter SNP. They reported that MMP-1 promoter variants exhibit differential responses to the ER isoforms $\alpha$ and $\beta$. As indicated before, the $2 \mathrm{G}$ promoter exhibited higher ( 2.5-fold) activity than the $1 \mathrm{G}$ variant regardless of the presence of ERs and estrogen. However, the proportional increase in $2 \mathrm{G}$ activity in the presence of the estrogen receptor $\beta$ (ER- $\beta$ ) isoform was less than that of the $1 \mathrm{G}$ variant. This study [18] was performed in the absence of mechanical loading which is a common feature of nearly all connective tissue cells in the body.

Mechanical loading is essential for maintaining homeostasis in connective tissues such as those of the knee joint. Connective tissues such as bone, ligaments, cartilage, and menisci consist of unique cell populations in their matrix that can adapt to changing mechanical environments. These tissues are in a continual state of dynamic flux as they experience mechanical input from ground reaction forces, gravity, barometric pressure, vibration, musculoskeletal movement, and contact with external objects [19]. Mechanotransduction, the conversion of mechanical stress (tensile, compression, shear, etc.) into cellular signals, is a well-accepted and a significant response mechanism in bone and other tissues [20]. Cells can also detect external mechanical signals through stretch-activated ion channels as the plasma membrane is deformed [21]. In this manner, mechanical stress applied to the cells can lead to changes in gene expression, which in turn can regulate the physiology of the tissue. Reportedly, many genes including MMP-1 are naturally repressed by joint loading and removal of joint loads can lead to a derepression of genes coding for catabolic mediators in menisci [22]. In addition, this pattern has also been observed in ex vivo rat tail tendon experiments. Load-deprived rat tail tendons exhibit a marked increase in pro-MMP-1 and MMP-1 protein production compared to time-zero controls, but when tails were subjected to static tensile loading, there was inhibition of the MMP-1 upregulation [23].

From the studies described above, it is evident that the 1 G/2G SNP in the MMP-1 gene can lead to differential responses to physiological stimuli. In the present studies, 
the combined impact of sex hormone receptor and mechanical stimuli on MMP-1 promoter activity was investigated. The studies were based on the hypothesis that mechanical stimuli will lead to controlled expression of the variants in the MMP-1 promoter in the presence of ligand-independent stimulation by the beta isoform of estrogen receptor $(E R-\beta)$. Thus, the inheritance of specific MMP-1 promoter variants could be a genetic risk factor for sex-hormone dependent connective tissue conditions or for musculoskeletal degeneration in sedentary or bedridden patients, or astronauts exposed to microgravity. Thus, MMP-1 may be regulated very differently in premenopausal and post-menopausal females depending on the variations in the hormone levels.

\section{Methods}

\section{Cell culture}

The rabbit synoviocyte cell line HIG-82 used in this study was previously shown to be negative for endogenous estrogen receptor alpha (ER- $\alpha)$ and ER- $\beta$ expression $[24,25]$ and was obtained from the American Type Culture Collection (Rockville, MD, USA). The cells were cultured in medium consisting of Ham's F-12 Nutrient Mixture (GIBCO Invitrogen, Carlsbad, CA, USA) supplemented with $10 \%$ fetal bovine serum (GIBCO Invitrogen) and 1\% antibiotic/ antimycotic (GIBCO Invitrogen) in a $5 \% \mathrm{CO}_{2}$ humidified air chamber at $37^{\circ} \mathrm{C}$. The cells were passaged 1:4 with $0.25 \%$ trypsin when $80 \%$ confluent.

For use in the Flexcell Streamer ${ }^{\text {rom }}$ system (Flexcell International Corporation, Hillsborough, NC, USA), the HIG-82 cells were grown in monolayer culture on $72 \mathrm{~mm} \times 25 \mathrm{~mm}$ microscope slides. Following sterilization, a set of three slides was placed in one square Petri plate (BD Falcon, San Jose, CA, USA). HIG-82 cells were collected, counted, and seeded on the slides at a density of $\sim 2.5 \times 10^{3}$ cells $/ \mathrm{cm}^{2}$. For a single experiment, two pairs of plates were designated as either shear exposure or non-shear controls. The cells were cultured in a humidified chamber with $5 \% \mathrm{CO}_{2}$ at $37^{\circ} \mathrm{C}$ for $48 \mathrm{~h}$ to allow time for the cells to attach onto the slides and reach approximately $80 \%$ confluency.

For tensile loading, HIG-82 cells were seeded on the central area of collagen type I coated Bioflex ${ }^{\circ} 6$-well cell culture plates (Randolph, NJ, USA) corresponding to the area of uniform strain for biaxial loading [26]. This yielded an approximate density of $\sim 2.5 \times 10^{3}$ cells $/ \mathrm{cm}^{2}$. Cell cultures were maintained in complete growth medium at $37^{\circ} \mathrm{C}$ under $5 \% \mathrm{CO}_{2}$ until approximately $80 \%$ confluent. Complete growth medium was replaced with transfection medium $24 \mathrm{~h}$ prior to loading. This protocol was adapted from [24] and [27].

\section{Sub-cloning of human MMP-1 promoter constructs}

The human 1G and 2G MMP-1 promoter constructs were a generous gift from Dr. C.E Brinckerhoff (Dartmouth
Medical School, NH, USA). Both the $1 \mathrm{G}$ and $2 \mathrm{G}$ constructs were sub-cloned into the pGL-3 luciferase expression vector as previously described by Achari et al. [18].

\section{Additional control and expression plasmids}

The expression vector for ER- $\beta$ was a generous gift from Dr. Koen Dechering (Organon, Oss, the Netherlands). The ER- $\beta$ insert was subsequently cleaved from the original vector and sub-cloned into the pSG5 vector with orientation and integrity of inserts confirmed by sequencing [25]. The pRLSV40 plasmid (Promega Corp., Madison, WI, USA) was used as an internal control in the dual luciferase assay. The pRLSV40 plasmid constitutively expresses the Renilla reniformis form of luciferase under the strong SV40 promoter. The ER- $\beta$ ABCDE and ER- $\beta$ ABCD constructs were derived from the full length ER- $\beta$ construct and sub-cloned into the pSG5 vector (Stratagene, Santa Clara, CA, USA). The sequence and orientation of the sub-cloned fragments were confirmed by sequencing.

\section{Transient transfection}

The following protocols for HIG-82 transfection with FuGENE 6 were adapted from those described by Kydd et al. [27] and $\mathrm{Lu}$ et al. [24]. HIG-82 cells were transfected with either pGL3-1G or pGL3-2G at a concentration of $0.5 \mu \mathrm{g} / \mathrm{ml}$ using the FuGene6 transfection reagent (Roche Molecular, Indianapolis, IN, USA) as directed by the manufacturer. In addition, the HIG-82 cells were co-transfected with pRLSV40 at a concentration of $0.05 \mu \mathrm{g} / \mathrm{ml}$ which acted as an internal control for the Dual Luciferase Assay System. To evaluate the expression of ER- $\beta$, cultures were also co-transfected with pSG5-ER $\beta$ or the ER- $\beta$ variant expression plasmids at a concentration of $0.5 \mu \mathrm{g} / \mathrm{ml}$ to create ER-specific positive cells. We previously determined the $0.5 \mu \mathrm{g} / \mathrm{ml}$ to be the ideal concentration of ER- $\beta$ for these experiments through an experiment using different concentrations of ER- $\beta$ ranging from 0.1 to $4 \mu \mathrm{g}$ [25]. The concentration of $0.5 \mu \mathrm{g} / \mathrm{ml}$ led to readily detectable levels without being overtly overexpressed [25]. For the duration of transfection, Ham's F-12 medium was supplemented with $1 \times$ serum replacement medium (SRM). Plasmid DNA was incubated with FuGENE 6 in 1-2 $\mathrm{ml}$ of this medium for $30 \mathrm{~min}$ prior to being added to the transfection culture medium to allow for DNA to form complexes with FuGENE 6.

The medium was removed by aspiration from the Petri plates, and the slides were rinsed with $5 \mathrm{ml}$ of $1 \times$ phosphate-buffered saline (PBS). The PBS was removed by aspiration and replaced with $10 \mathrm{ml}$ SRM, and $300 \mu \mathrm{l}$ of transfection mixture was added dropwise to each plate. The plates were incubated in air with $5 \% \mathrm{CO} 2$ at $37^{\circ} \mathrm{C}$ for 3 or $6 \mathrm{~h}$. After transfection, the loading regimen was performed. 


\section{Loading regimen}

The pattern of loading regimen is briefly described below and follows the previously published loading pattern [13,28-32]. It was designed to represent physiological conditions, where loading events are episodic. The amplitudes of mechanical loading chosen are comparable to recent studies [29-34] and the frequency of loading was selected to match the stride frequency of a slow $1-\mathrm{m} / \mathrm{s}$ walk [35].

\section{Fluid flow-induced shear stress}

Shear stress was applied using the Flexcell Streamer ${ }^{\mathrm{TM}}$ parallel plate flow chamber system (Figure 1) from Flexcell International Corporation. The apparatus was placed in an incubator $30 \mathrm{~min}$ prior to and for the duration of the experimental run and maintained at $37^{\circ} \mathrm{C}$ under $5 \%$ $\mathrm{CO}_{2}$. The cell culture slides were inserted into the Streamer $^{\mathrm{TM}}$ unit. The loading regime consisted of $60 \mathrm{~s}$ pulsatile flow oscillating between 10 and $0.8 \mathrm{dyn} / \mathrm{cm}^{2}$ at $0.5 \mathrm{~Hz}$ followed by $14 \mathrm{~min}$ at $0.8 \mathrm{dyn} / \mathrm{cm}^{2}$. The $15-\mathrm{min}$ cycle was repeated for $8 \mathrm{~h}$.

\section{Equibiaxial stretch}

The cells were exposed to equibiaxial stretch using the Flexcell Tension Plus ${ }^{\mathrm{Tm}}$ system (Figure 1) contained in an incubator maintained at $37^{\circ} \mathrm{C}$ under $5 \% \mathrm{CO}_{2}$. The loading regime consisted of $60 \mathrm{~s}$ of EBS oscillating between $2 \%$ and $9 \%$ elongation at a frequency of $0.5 \mathrm{~Hz}$ followed by $14 \mathrm{~min}$ of static $2 \%$ elongation. The 15 -min cycle was repeated for $8 \mathrm{~h}$.

\section{Luciferase assay}

Immediately following the final rest period of the loading regimes, the cells were washed with PBS and lysed with $1 \times$ passive lysis buffer (Promega Corp.). Luciferase activity within cell lysates was assessed using the Dual Luciferease ${ }^{\oplus}$ Reporter Assay System (Promega Corp.) and a Turner TD-20 luminometer.

\section{Statistical analysis}

All loading and transfection experiments were performed in triplicate and repeated at least three times. Statistical analysis of the data was performed using multiple comparisons of variance (two-way, three-way ANOVAs) and the Tukey HSD test calculated on STATA 10 software.

\section{Results}

Effect of fluid flow shear stress on MMP-1 promoter activity The effect of applying the fluid flow shear stress was tested on the HIG-82 which had been transfected with the $1 G$ and $2 G$ variants of the MMP-1 promoter. The HIG-82 cell line was first transfected with $1 G$ and $2 G$ variants of the MMP-1 promoter. Next, the transfected cells were subjected to $8 \mathrm{~h}$ of intermittent pulsating 0.8 to 10 dynes $/ \mathrm{cm}^{2} 0.5 \mathrm{~Hz}$ (conditions shown to be optimal in preliminary experiments (data not shown)) for fluid flow-induced shear stress in the flex cell streamer apparatus. Transfected cells placed in the apparatus, not subjected to shear stress were used as controls. A comparison of the $1 G$ and $2 G$ promoters showed that the $2 \mathrm{G}$ allele was associated with significantly higher activity

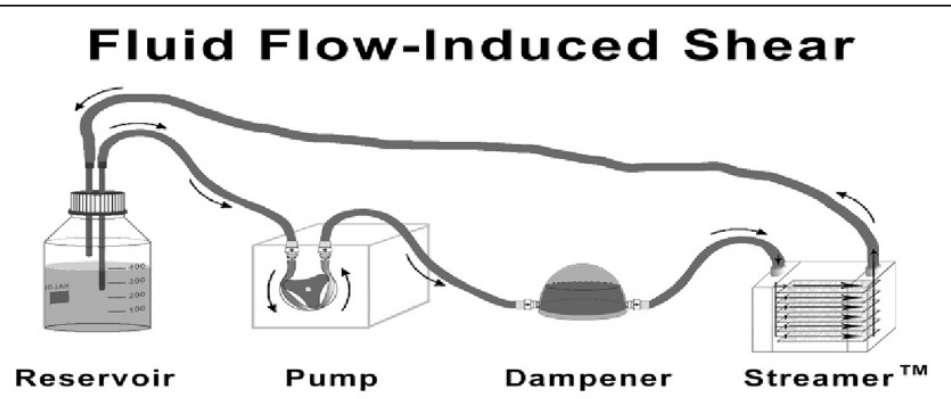

Equibiaxial Stretch

Cell seeding

Side
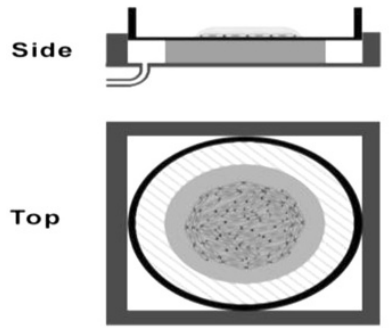

Equibiaxial Stretch

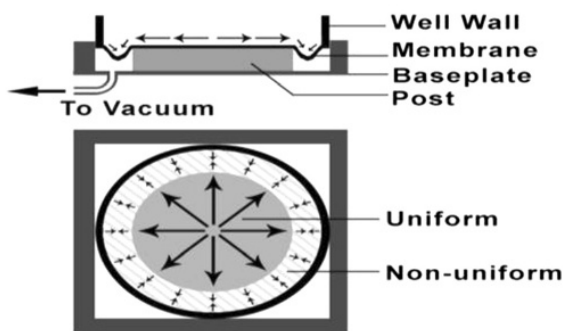

Figure 1 The two modes of loading, sheer and equibiaxial stretch, were applied using two commercial apparatus (top and bottom). 
than the 1G allele under control conditions $(p<0.05)$ with the $2 \mathrm{G}$ promoter activity $\sim 1.8$-fold higher than that for the $1 \mathrm{G}$ variant, respectively (Figure 2 ). The promoter activity was significantly increased ( $\sim 3$ fold) for both the $1 G$ and $2 G$ variants of the MMP-1 promoters when transfected cells were subjected to the shear stress protocol $(p<0.05)$ (Figure 2). These results suggest that shear stress enhances the promoter activity of the MMP-1 gene and further suggests that shear stress exposure leads to greater effects on the $2 \mathrm{G}$ promoter variant of the MMP-1 gene.

\section{Equibiaxial stretch does not influence MMP-1 promoter activity}

The second mode of mechanical stress tested was the effect of cyclic biaxial stretch using the Flexcell Tension Plus system. The HIG-82 cells were exposed to $8 \mathrm{~h}$ of intermittent cyclic $2 \%-9 \%, 0.5 \mathrm{~Hz}$ biaxial stretch on collagen I coated culture plates $\left(\right.$ Bioflex $\left.^{\circ}\right)$. The results depicted in Figure 3 show that MMP-1 promoter activity for either SNP variant was not significantly different compared to the unstretched controls $(p=0.3)$. Typically, the polymorphism of the MMP-1 promoter did affect the constitutive promoter activity of the $1 \mathrm{G}$ and $2 \mathrm{G}$ alleles for the unloaded and stretched conditions, respectively. There were no significant interactions between the 1G/2G SNP and biaxial stretch exposure $(p=0.3)$.

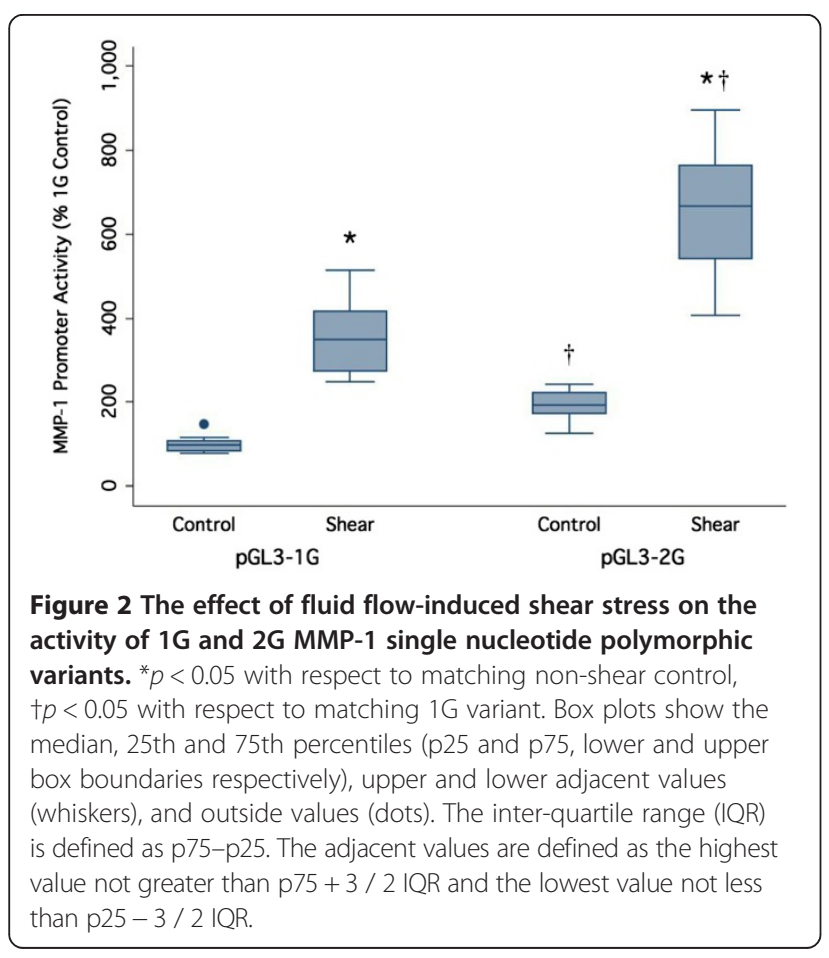

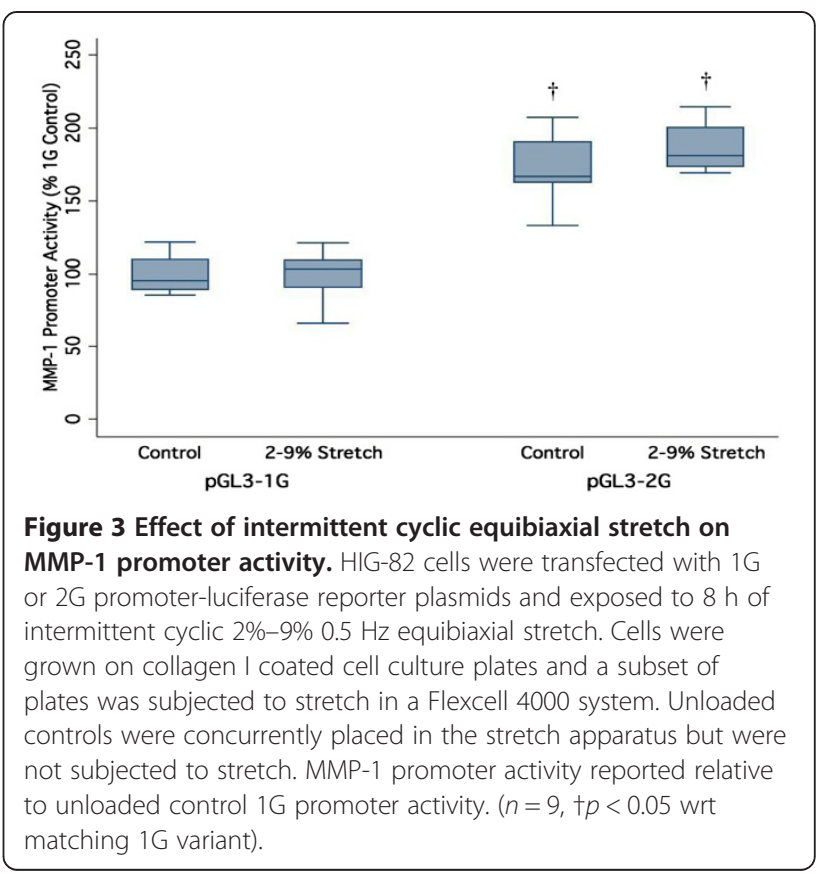

\section{Role of biological and mechanical stimuli on MMP-1 promoter activity}

As described earlier, shear stress has the ability to influence the activity of the MMP-1 promoter. Previously, we have also demonstrated that the presence of the ER isoforms ER- $\alpha$ or ER- $\beta$ differentially led to increases in the activity of the $1 \mathrm{G}$ and $2 \mathrm{G}$ MMP-1 promoter variants in HIG-82 cells [18]. In this part of the study, both mechanical stress and ER- $\beta$ were introduced concurrently in the HIG-82 model system to study their combined effects. The studies focused on ER- $\beta$ as this isoform is very prevalent in connective tissues.

HIG-82 cells were transfected with the ER- $\beta$ expression vector pSG5-ER $\beta$ concurrently with the $1 G$ or $2 G$ variant of the MMP-1 promoter constructs. After transfection and $8 \mathrm{~h}$ growth in non-shear control conditions, the ER- $\beta$ expressing cells exhibited MMP- 1 promoter activity that was 3.5 -fold higher than the ER negative controls (Figure 4A). This is a similar MMP-1 promoter response to ER- $\beta$ as was reported previously by Achari et al. [18]. Next, the transfected cells were subjected to shear stress conditions. The ER- $\beta$ transfected cells exhibited a mean 2- and 2.5-fold higher promoter activity than those of the shear-exposed ER negative cells for the $1 G$ and $2 G$ variants, respectively (Figure $4 A$ ). In the presence of the $2 \mathrm{G}$ allele, shear stress and ER- $\beta$ also combined to produce a significantly higher MMP-1 promoter activity than in the controls. The effect of ER- $\beta$ in the absence of estrogen was a two- to threefold increase in promoter activity. Thus, the effects appeared to be additive rather than synergistic. 


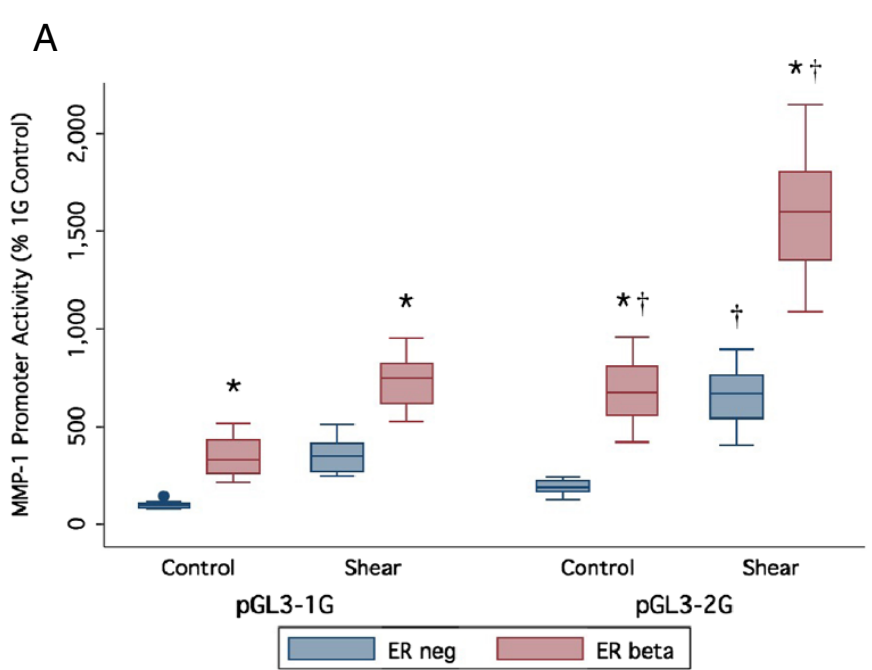

B

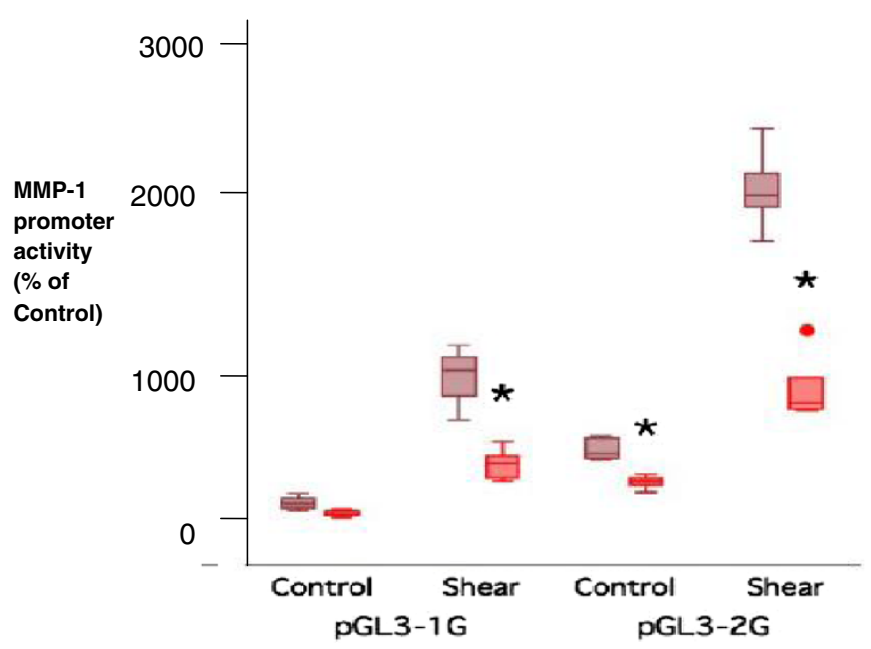

Figure 4 Combined effect of ER $\beta$ and effect of $17 \beta$-estradiol. (A) Combined effect of ER $\beta$ expression and shear stress on MMP- 1 promoter activity. HIG-82 cells were exposed to $8 \mathrm{~h}$ of intermittent pulsatile $0.8-10$ dynes/cm $20.5 \mathrm{~Hz}$ fluid flow-induced shear stress in a Flexcell Streamer apparatus. MMP-1 promoter activity reported relative to ER negative, unloaded control $1 \mathrm{G}$ promoter activity. $\left(n=15,{ }^{*} p<0.05\right.$ with respect to matching ER negative controls, $\uparrow p<0.05$ with respect to matching $1 \mathrm{G}$ variant). (B) Effect of $17 \beta$-estradiol on ER- $\beta$-mediated response for MMP-1 promoter activity. HIG-82 cells were transfected with $1 \mathrm{G}$ or $2 \mathrm{G}$ promoter-luciferase reporter plasmids \pm co-transfection with ER- $\beta$ expression plasmids then exposed to $8 \mathrm{~h}$ intermittent pulsatile $0.8-10$ dynes/cm $20.5 \mathrm{~Hz}$ fluid flow-induced shear stress in a Flexcell Streamer apparatus with, $\pm 10^{-8} \mathrm{M} 17 \beta$-estradiol (+shown by orange bars) in medium. MMP-1 promoter activity reported relative to ER $\beta$ positive, unloaded control $1 \mathrm{G}$ promoter activity. ( $n=9$ except ER $\beta+$ Estrogen $n=6$, *n.s. wrt matching ER negative, 0 M estrogen controls).

Interestingly, in the presence of the ligand $17 \beta$-Estradiol, the activity of both MMP-1 alleles (1G and 2G) exhibited a proportional decrease (Figure $4 B$ ) when ER- $\beta$ was present. The effect of $10^{-8} \mathrm{M} 17 \beta$-estradiol, a saturating dose of estradiol $[18,24,25]$, on cells expressing ER- $\beta$ led to promoter activities being depressed $28 \%$ to $67 \%$ compared to their corresponding control with no hormones. The effect of ER- $\beta$ in the absence of estrogen was a two to threefold increase in promoter activity; however, in the presence of ligand, the effect of ER- $\beta$ was largely abrogated (Figure 4B).

\section{Effect of ER- $\beta$ variants on MMP- 1 promoter SNP variant activity under shear stress conditions}

The ER- $\beta$ protein contains several specialized domains associated with particular mechanisms by which it influences gene expression, specifically the AF-1 and AF-2 domains [36]. To determine the potential role of the AF-1 and AF-2 domains in influencing the MMP-1 promoter activity, HIG-82 cells were transfected with truncated versions of the ER- $\beta$ gene (pSG5-ER $\beta$ ABCDE and pSG5-ER $\beta$ ABCD) (See Figure $5 \mathrm{~A}$ for a diagram of ER- $\beta$ domain structure and variants) and either pGL3-1G or pGL3-2G. 

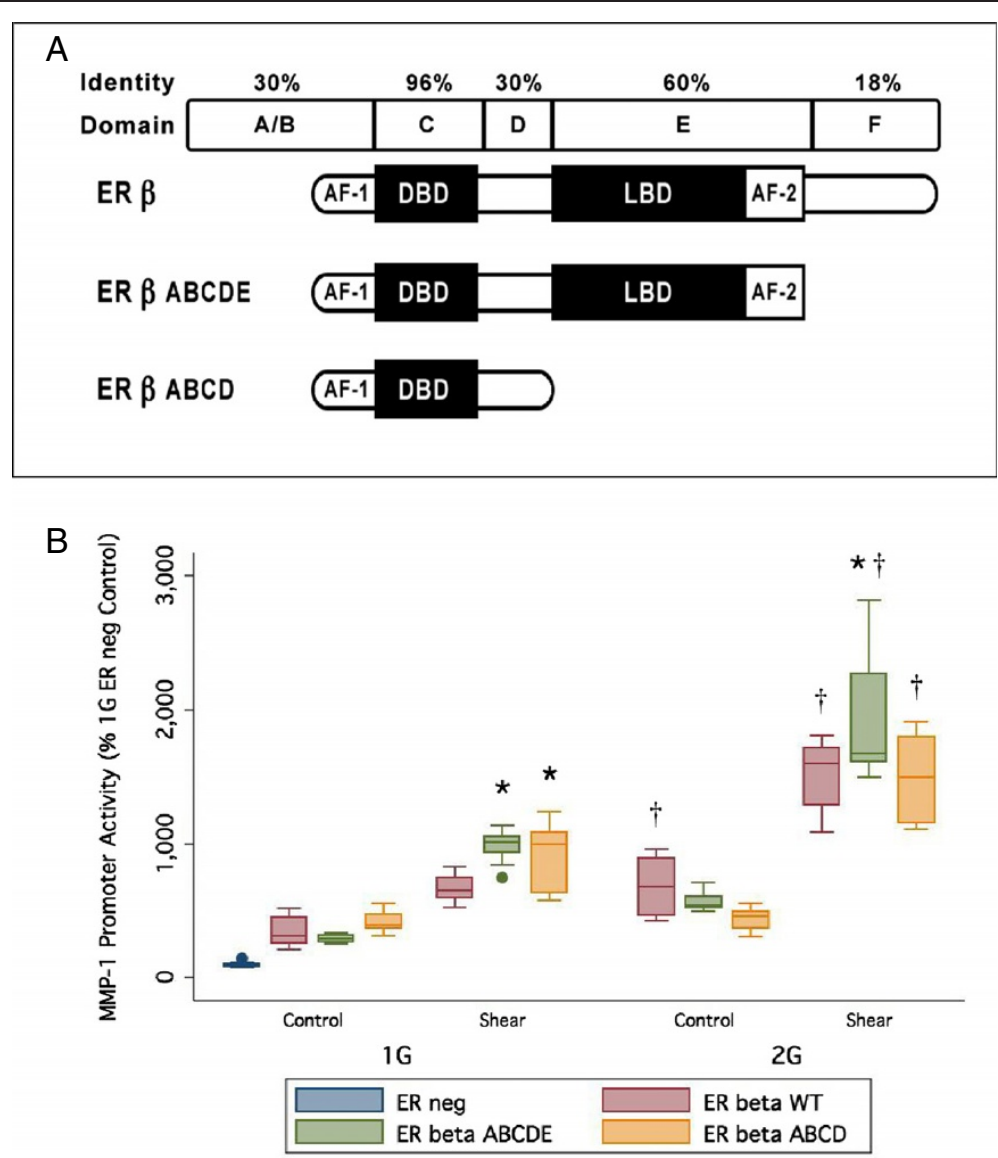

Figure $\mathbf{5}$ Classic functional domains and effect of $\mathbf{N}$-terminal ER $\boldsymbol{\beta}$ variants. (A) Classic functional domains of estrogen receptors (ER). (B) Effect of N-terminal truncated ER $\beta$ variants on MMP-1 promoter activity. AF-1 and AF-2 are activation function regions, DBD is the DNA binding domain, and $L B D$ is the ligand binding domain. $E R \beta A B C D E$ and $E R \beta A B C D$ are truncated variants lacking the $F$ and $E+F$ domains, respectively. HIG-82 cells were transfected with $1 \mathrm{G}$ or $2 \mathrm{G}$ promoter-luciferase reporter plasmids \pm co-transfection with ER- $\beta$ variant expression plasmids then exposed to 8 hs intermittent pulsatile $0.8-10$ dynes $/ \mathrm{cm}^{2} 0.5 \mathrm{~Hz}$ fluid flow-induced shear stress in a Flexcell Streamer apparatus. MMP-1 promoter activity reported relative to ER negative, unloaded control 1 G promoter activity. ( $n=9$ except 2 G ER- $\beta$ ABCD $n=6,{ }^{*} p<0.05$ wrt WT ER- $\beta,+p<0.05$ wrt matching $1 \mathrm{G}$ variant).

Transfected cells were exposed to fluid-flow shear stress as in the previous experiments. When HIG-82 cells transfected with ER- $\beta$ variants lacking the $F$ domain or the $\mathrm{E}+\mathrm{F}$ domains were grown for $8 \mathrm{~h}$ in non-shear control conditions, there was no significant difference in MMP-1 promoter activity between the full length ER- $\beta$ and the truncated ER variants (Figure $5 \mathrm{~B}$ ). After $8 \mathrm{~h}$ under shear stress conditions, the ER- $\beta$ ABCDE variant had a positive effect on MMP-1 promoter activity compared to wild-type (WT) ER- $\beta(p<0.05)$ for both the $1 \mathrm{G}$ and $2 \mathrm{G}$ promoter alleles. When the statistical effect size was calculated, the effect of the ER- $\beta$ variants was small. The ER- $\beta$ ABCD variant showed no significant difference compared to WT ER- $\beta$ for the 2G MMP-1 promoter allele $(p>0.05)$ (see Figure $5 \mathrm{~B})$. Therefore, in this ligand-independent stimulation by ER- $\beta$, the removal of domains $\mathrm{E}$ and $\mathrm{F}$ together has only minor modulatory impact, likely indicating that the response to shear is associated with unique sequences in the AF-1 domain of ER- $\beta$.

\section{Discussion}

Hormonal changes and mechanical overuse have also been attributed to influence the degradation of the cartilage in knee, a characteristic feature of OA. The higher prevalence of $\mathrm{OA}$ in women than in men suggests that sex differences exist in the development of this disease. Furthermore, post-menopausal women are at higher risk suggesting that hormonal changes may contribute to the development of this disease. Indeed, it is reported that tissues of the knee have receptors for sex hormones and they respond to menopause and menstrual cycle changes [6]. However, how the impact caused by changing hormonal levels on the joint tissues is not clear at the molecular level and the present study focused on this issue. 
MMP-1 has been implicated in the degradation of cartilage in the articulating surfaces of the synovial joints such as the knee. The presence of a SNP in the MMP-1 promoter consists of a deletion/insertion (1G/2G) of a guanine nucleotide, and several reports suggest that the 2G allelic form leads to enhanced MMP-1 expression $[37,38]$. The present study examined the influence of biomechanical and hormonal factors on the expression of the two allelic forms $(1 \mathrm{G} / 2 \mathrm{G})$ of the MMP-1 gene. The results presented in this study of human MMP-1 promoter variants suggests that the $2 \mathrm{G}$ allele has the capacity to enhance the response patterns to mechanical stimuli in the absence of estrogen hormone. This suggests that females with $2 \mathrm{G}$ allelic form may be at higher risk for the development of this disease when the estrogen levels are low, e.g., menopause.

In this study, we evaluated the response of the $1 \mathrm{G}$ or $2 \mathrm{G}$ forms of the MMP-1 promoter to mechanotransduction stimuli such as the fluid-flow-induced shear stress and equibiaxial stretch. Of the two types of mechanical influences, only shear stress had the ability to elevate the $1 \mathrm{G}$ and $2 \mathrm{G}$ MMP-1 promoter activity. Moreover, the $2 \mathrm{G}$ form of MMP-1 exhibited a significantly higher $(p<$ 0.05 ) activity level than $1 \mathrm{G}$ both constitutively and also under the control of this mechanical stress (Figure 2). This response suggests that the HIG-82 cell line possesses a mechanism for sensing fluid flow shear which triggers a signaling pathway affecting the MMP-1 promoter. These results are in agreement with the extensive work by Sun and Yokota who have shown that lower levels of shear (1-5 dynes/cm2) downregulate MMP-1 expression whereas higher levels of shear (6-20 dynes/ $\mathrm{cm} 2$ ) lead to an upregulation of MMP-1 expression in rheumatoid arthritis synoviocytes [33,39-42]. Studies conducted using osteoblasts suggest that activation of the MAPK pathway, an increase in COX-2 expression, and release of prostaglandins are important for cellular mechanotransduction events [43]. Furthermore, this study also suggests that ER- $\beta$ plays ligand-dependent and ligand-independent roles in mechanical signaling in osteoblasts. However, the mechanism by which the mechanical shear stress is translated into changes in MMP-1 expression is not well understood.

Equibiaxial stretch, a second mode of mechanical stimulation tested in the current study, did not produce a significant change in MMP-1 promoter activity (Figure 3). This was unexpected since stretch has been reported to increase MMP-1 expression in human osteoblasts [44] and is reported to suppress MMP-1 expression in human vascular smooth muscle [45]. Several different substrates were tested including plain plastic loading membranes and ones coated with pronectin (from Flexcell Inc.) (data not included); however, none showed a difference between stretched and non-stretched conditions. Therefore, the specific substrate attachment mediating the mechanotransduction is not a likely explanation for the lack of response. In vascular smooth muscle cells, $4 \mathrm{~h}$ of cyclic $25 \%$ stretch, but not 7\% stretch induced activation of JNK and p38 MAPK [46], but this could have been part of an injury response at this high level of stretch. However, it is possible that the magnitude of stretch used in this study was not sufficient to induce a response. Additionally, the choice of a rabbit cell line as a model system may have had an impact since cyclic stretch loading in a rabbit flexor tendon which inhibited MMP-3 expression, failed to produce a change in MMP-1 expression [47]. The stretch mechanosensory signal cascade in HIG-82 cells, if present, was either not activated by the stretch protocol used in this study or did not interact with the MMP-1 promoter SNP.

Mechanical stimuli are not the only factors known to influence MMP-1 expression. The presence of alpha and beta form of estrogen receptors has been demonstrated in human chondrocytes [48]. The expression of ERs in HIG-82 cells has been shown to alter MMP-1 expression patterns, and the promoter activity response is different for $1 \mathrm{G}$ and $2 \mathrm{G}$ alleles [18]. The current study found a similar significant interaction between the effects of ER- $\beta$ expression, sheer stress, and the $1 \mathrm{G} / 2 \mathrm{G}$ SNP on MMP-1 promoter activity, supporting the hypothesis that the combination of ER and mechanical stimulation had a additive effects on MMP- 1 promoter activity. The reason for these elevation is likely due to the activation of different signaling pathways. When the $1 \mathrm{G}$ allele is present, the combined effects of shear and ER- $\beta$ expression did not lead to the same level of activation as was observed with the $2 \mathrm{G}$ allele, where a significant additive interaction between the shear and ER effects were observed. This supports the hypothesis that the presence of the additional ETS site in the $2 \mathrm{G}$ allele alters the response pattern of this model cell system to complex combinations of stimuli.

MMP-1 has several proximal promoter elements, but these two distal transcriptional regulatory elements (Ets and AP-1 sites at nt $-1,607$ and $-1,602$ ) appear to play an important role in the stimulation of MMP-1 promoter activity. In addition, a separate study which focused on the role of reactive oxygen species on the elevation of MMP-1 promoter activity also established that site-directed mutagenesis of these Ets and AP-1 sites at nt $-1,607$ and $-1,602$ led to significant decreases in the activity of the MMP-1 promoter [49]. For activation of the $2 \mathrm{G}$ allele, the ER- $\beta$ receptor likely acts via a non-classical estrogen response element (ERE)-independent activation pathway since the MMP-1 promoter does not contain an ERE sequence [50]. ERs are known to interact with AP-1 transcription factors, particularly c-Jun, c-Fos, and Fra-1 [51-53], and as mentioned above, 
the AP-1 site at $-1,602$ immediately adjacent to the $-1,607$ SNP is known to be an important control point for MMP-1 expression [18]. Since there is no ERE in the MMP-1 promoter and ER- $\beta$ stimulates the $2 \mathrm{G}$ allelic form of MMP-1, ER- $\beta$ likely contributes to a multi-protein complex at the $-1,607$ bp AP-1/ETS site. Although the exact mechanisms by which shear and ER are affecting the MMP-1 promoter activity are unknown, it likely involves these ETS and AP-1 sites since the $2 \mathrm{G}$ allele is influenced by the interaction between these stimuli.

The binding of $17 \beta$-estradiol acts to inhibit the positive effect of ER- $\beta$ on MMP-1 activity. In light of the fact that estrogen levels drop considerably in postmenopausal women, this could explain at least part of the increased prevalence, incidence, and severity of $\mathrm{OA}$ in post-menopausal women [54] as this negative control on MMP-1 expression would be diminished and one could expect a potential elevation in MMP-1 production. Estrogen has also been shown to repress MMP-13 promoter activity in the presence of ER- $\beta$ [25], and this has already been shown for MMP-1 promoter activity in HIG-82 cells [18] albeit without the additional factor of shear stress. Ligand-dependent ER- $\beta$ action at AP-1 elements has been shown to be inhibitory [55]. Since ligand binding initiates dimerization of ERs [56], it is possible that ER- $\beta$ monomers have a positive effect on AP-1 elements in the MMP- 1 promoter while ER- $\beta$ homodimers have a reduced or negative effect.

The effect of two truncated variants of ER- $\beta$ was tested on the $1 \mathrm{G} / 2 \mathrm{G}$ promoter SNPs of MMP-1. In the splice variant labeled ER- $\beta$ ABCDE, the $F$ domain was removed, and in ER- $\beta$ ABCD, the $E$ and $F$ domains were removed. In ER- $\beta$ ABCDE, the $C$ terminal " $F$ " domain, which is reported to impact receptor dimerization and modulate gene transcription in a ligand-specific manner was deleted reviewed in [57]. In ER- $\beta$ ABCD, the ligand binding domain $\mathrm{E}$ and the domain $\mathrm{F}$ were deleted. We observed that the activity of $1 \mathrm{G}$ or $2 \mathrm{G}$ forms of MMP-1 were similar or modestly higher in the presence of the truncated forms of ER- $\beta$ (ER- $\beta$ ABCD and ER- $\beta$ $A B C D E)$ to what was observed with WT ER- $\beta$. Moreover, the 2G SNP exhibited somewhat higher activity levels than the corresponding $1 G$ variant in the presence of all truncated ER- $\beta$ versions and sheer stress (Figure 5). Thus, the responsive elements in the ER- $\beta$ to stress are likely in the AF-1 domain.

In summary, the results of these studies suggest that the dual influence of mechanotransduction and ER- $\beta$ leads to an elevation in the activity of the two promoter SNP variants of MMP-1. The 2G SNP of MMP-1 exhibits a higher activity level than the corresponding $1 G$ variant under the influence of these physiological stimuli. In addition, the activation of these physiological stimuli is attenuated by the action of the ligand (17- $\beta$ estradiol). Interestingly, equibiaxial stretch did not influence the activity levels of $1 \mathrm{G}$ and $2 \mathrm{G}$ SNPs, thereby suggesting that different types of mechanotransduction may influence different genes differently.

\section{Conclusions}

These findings may also be very relevant to the responsiveness of different connective tissues to changing hormonal levels especially in women and suggest that certain genotypes may mean a higher risk for the development of OA.

\section{Abbreviations \\ OA: osteoarthritis; MMP-1: matrix metalloproteinase 1; SNP: single nucleotide polymorphism; 1G: allelic variant of MMP-1; 2G: allelic variant of MMP-1; HIG-82: rabbit synoviocyte cell line; ER: estrogen receptor; ER- $\beta$ : estrogen receptor beta; ER-a: estrogen receptor alpha; TNF-a: transforming necrosis factor-alpha; IL-1 $\beta$ : interleukin-1 beta; pGL-3: luciferase expression vector.}

\section{Competing interests}

The authors declare that they have no competing interests.

\section{Authors' contributions}

JDT was primarily involved in the data acquisition of data, analysis, and interpretation of data. TL was involved in the designing of the constructs use in this study. She was also involved in data acquisition in the initial design of the study. YA has been involved in drafting the manuscript and revising it critically for important intellectual content. DAH has been involved in the primary conception and design of the study and has played an active role in the revising it critically for important intellectual content. NGS was involved in the critical review of the manuscript and played an active role in the design of the biomechanical aspects of this project. All authors read and approved the final manuscript.

\section{Acknowledgements}

The authors gratefully acknowledge the financial support provided for these studies through research grants from the Canadian Institutes for Health Research (CIHR), Institute for Gender and Health (DAH), and Alberta Innovates Health Solutions Team Grant in Osteoarthritis ((1) 20080170 (2) 200700596) (NGS and DAH), The Canada Foundation for Innovation and The Arthritis Society. The authors thank Carol Hewitt for the excellent technical expertise.

\section{Author details}

${ }^{1}$ McCaig Institute for Bone and Joint Health, University of Calgary, 3330 Hospital Drive NW, Calgary, AB T2N 4 N1, Canada. ${ }^{2}$ Schulich School of Engineering, University of Calgary, 2500 University Drive NW, Calgary, AB T2N $1 \mathrm{~N} 4$, Canada.

Received: 12 August 2014 Accepted: 13 September 2014

V.:

\section{References}

1. Sutton KM, Bullock JM: Anterior cruciate ligament rupture: differences between males and females. J Am Acad Orthop Surg 2013, 21(1):41-50.

2. Park SK, Stefanyshyn DJ, Ramage B, Hart DA, Ronsky JL: Alterations in knee joint laxity during the menstrual cycle in healthy women leads to increases in joint loads during selected athletic movements. Am J Sports Med 2009, 37(6):1169-1177. PMID: 19289541.

3. Zazulak BT, Paterno M, Myer GD, Romani WA, Hewett TE: The effects of the menstrual cycle on anterior knee laxity: a systematic review. Sports Med 2006, 36(10):847-862. Review. PMID: 17004848.

4. Sciore P, Frank CB, Hart DA: Identification of sex hormone receptors in human and rabbit ligaments of the knee by reverse transcriptionpolymerase chain reaction: evidence that receptors are present in tissue from both male and female subjects. J Orthop Res 1998, 16(5):604-610. PMID: 9820285. 
5. Liu SH, al-Shaikh R, Panossian V, Yang RS, Nelson SD, Soleiman N, Finerman GA, Lane JM: Primary immunolocalization of estrogen and progesterone target cells in the human anterior cruciate ligament. J Orthop Res 1996, 14(4):526-533.

6. Boyan BD, Hart DA, Enoka RM, Nicolella DP, Resnick E, Berkley KJ, Sluka KA, Kwoh CK, Tosi LL, O'Connor MI, Coutts RD, Kohrt WM: Hormonal modulation of connective tissue homeostasis and sex differences in risk for osteoarthritis of the knee. Biol Sex Differ 2013, 4(1):3.

7. Hellio Le Graverand MP, Eggerer J, Sciore P, Reno C, Vignon E, Otterness I, Hart DA: Matrix metalloproteinase-13 expression in rabbit knee joint connective tissues: influence of maturation and response to injury. Matrix Biol 2000, 19(5):431-441.

8. Hellio Le Graverand MP, Vignon E, Otterness IG, Hart DA: Early changes in lapine menisci during osteoarthritis development: part I: cellular and matrix alterations. Osteoa rthritis Cartilage 2001, 9(1):56-64. PMID: 11178948

9. Hellio Le Graverand MP, Vignon E, Otterness IG, Hart DA: Early changes in lapine menisci during osteoarthritis development: part II: molecular alterations. Osteoarthritis Cartilage 2001, 9(1):65-72

10. Haslauer $C M$, Elsaid KA, Fleming BC, Proffen BL, Johnson VM, Murray MM: Loss of extracellular matrix from articular cartilage is mediated by the synovium and ligament after anterior cruciate ligament injury. Osteoarthritis Cartilage 2013, 21(12):1950-1957. PMID: 24036379.

11. Vincenti MP, Brinckerhoff CE: Transcriptional regulation of collagenase (MMP-1, MMP-13) genes in arthritis: integration of complex signaling pathways for the recruitment of gene-specific transcription factors. Arthritis Res 2002, 4(3):157-164. PMID: 128926.

12. Rutter JL, Mitchell TI, Butticè G, Meyers J, Gusella JF, Ozelius LJ, Brinckerhoff CE: A single nucleotide polymorphism in the matrix metalloproteinase-1 promoter creates an Ets binding site and augments transcription. Cancer Res 1998, 58(23):5321-5325. PMID: 9850057.

13. Jurajda M, Muzík J, Izakovicová Hollá L, Vácha J: A newly identified single nucleotide polymorphism in the promoter of the matrix metalloproteinase-1 gene. Mol Cell Probes 2002, 16(1):63-66.

14. Tasevski V, Sorbetti JM, Chiu SS, Shrive NG, Hart DA: Influence of mechanical and biological signals on gene expression in human MG-63 cells: evidence for a complex interplay between hydrostatic compression and vitamin D3 or TGF-beta1 on MMP-1 and MMP-3 mRNA levels. Biochem Cell Biol 2005, 83(1):96-107. PMID: 15746971.

15. Biondi ML, Turri O, Leviti S, Seminati R, Cecchini F, Bernini M, Ghilardi G, Guagnellini E: MMP1 and MMP3 polymorphisms in promoter regions and cancer. Clin Chem 2000, 46(12):2023-2024. PMID: 11106348.

16. Lepetsos P, Pampanos A, Kanavakis E, Tzetis M, Korres D, Papavassiliou AG, Efstathopoulos N: Association of MMP-1 -1607 1G/2G (rs1799750) polymorphism with primary knee osteoarthritis in the Greek population. J Orthop Res 2014, [Epub ahead of print] PMID: 24838892

17. Barlas 1O, Sezgin M, Erdal ME, Sahin G, Ankarali HC, Altintas ZM, Türkmen E: Association of $(-1,607) 1 \mathrm{G} / 2 \mathrm{G}$ polymorphism of matrix metalloproteinase-1 gene with knee osteoarthritis in the Turkish population (knee osteoarthritis and MMPs gene polymorphisms). Rheumatol Int 2009, 29(4):383-388. PMID: 18802702.

18. Achari Y, LU T, Hart DA: Polymorphisms in the promoter regions for human MMP-1 and MMP-13 lead to differential responses to the alpha and beta isoforms of estrogen receptor and their ligand in vitro. Biochim Biophys Acta 2008, 1782(6):391-400. PMID: 18358246.

19. Banes AJ, Horesovsky G, Larson C, Tsuzaki M, Judex S, Archambault J, Zernicke R, Herzog W, Kelley S, Miller L: Mechanical load stimulates expression of novel genes in vivo and in vitro in avian flexor tendon cells. Osteoarthritis Cartilage 1999, 7(1):141-153. PMID: 10367022.

20. Duncan $\mathrm{RL}$, Turner $\mathrm{CH}$ : Mechanotransduction and the functional response of bone to mechanical strain. Calcif Tissue Int 1995, 57:344-358.

21. Mikuni-Takagaki Y: Mechanical responses and signal transduction pathways in stretched osteocytes. J Bone Miner Metab 1999, 17:57-60.

22. Natsu-ume T, Majima T, Reno C, Shrive NG, Frank CB, Hart DA: Menisci of the rabbit knee require mechanical loading to maintain homeostasis: cyclic hydrostatic compression in vitro prevents derepression of catabolic genes. J Orthop Sci 2005, 10:396-405.

23. Arnoczky SP, Tian T, Lavagnino M, Gardner K: Ex vivo static tensile loading inhibits MMP-1 expression in rat tail tendon cells through a cytoskeletally based mechanotransduction mechanism. J Orthop Res 2004, 22:328-333.

24. Lu T, Achari $Y$, Sciore $P$, Hart DA: Estrogen receptor alpha regulates matrix metalloproteinase-13 promoter activity primarily through the AP-1 transcriptional regulatory site. Biochim Biophys Acta 2006, 1762(8):719-731. PMID: 16919424

25. Lu T, Achari Y, Rattner JB, Hart DA: Evidence that estrogen receptor beta enhances MMP-13 promoter activity in HIG-82 cells and that this enhancement can be influenced by ligands and involves specific promoter sites. Biochem Cell Biol 2007, 85(3):326-336. PMID: 17612627.

26. Vande Geest JP, Di Martino ES, Vorp DA: An analysis of the complete strain field within Flexercell membranes. J Biomech 2004, 37(12):1923-1928. PMID: 15519600.

27. Kydd AS, Achari Y, Lu T, Sciore P, Rattner JB, Hart DA: The healing rabbit medial collateral ligament of the knee responds to systemically administered glucocorticoids differently than the uninjured tissues of the same joint or the uninjured MCL. Biochim Biophys Acta Mol basis Dis 2005, 1741:289-299.

28. Majima T, Marchuk LL, Shrive NG, Frank CB, Hart DA: In-vitro cyclic tensile loading of an immobilized and mobilized ligament autograft selectively inhibits mRNA levels for collagenase (MMP-1). J Orthop Sci 2000, 5:503-510.

29. Myers KA, Rattner JB, Shrive NG, Hart DA: Osteoblast-like cells and fluid flow: cytoskeleton-dependent shear sensitivity. Biochem Biophys Res Commun 2007, 364:214-219.

30. Myers KA, Rattner JB, Shrive NG, Hart DA: Hydrostatic pressure sensation in cells: integration into the tensegrity model. Biochem Cell Biol 2007 85:543-551.

31. Myers KA, Rattner JB, Shrive NG, Hart DA: Response of human osteoblast-like cells to fluid flow shear: a potential role for the microtubule network and primary ciliums. Clinical Investigative Medicine 2007, 30(4):S90.

32. Myers KA, Shrive NG, Hart DA: A novel apparatus applying long term intermittent cyclic hydrostatic pressure to in vitro cell cultures. J Biosci Bioeng 2007, 103(6):578-581.

33. Yokota H, Goldring MB, Sun HB: CITED2-mediated regulation of MMP-1 and MMP-13 in human chondrocytes under flow shear. J Biol Chem 2003, 278(47):47275-47280.

34. Momberger TS, Levick JR, Mason RM: Mechanosensitive synoviocytes: $\mathrm{a} \mathrm{Ca}^{2+}$ - PKC-MAP kinase pathway contributes to stretch-induced hyaluronan synthesis in vitro. Matrix Biol 2006, 25:306-316.

35. Nilsson J, Thorsternsson A: Adaptability in frequency and amplitude of leg movements during human locomotion at different speeds. Acta Physiol Scand 1987, 129(1):107-114.

36. Zwart W, de Leeuw R, Rondaij M, Neefjes J, Mancini MA, Michalides R: The hinge region of the human estrogen receptor determines functional synergy between AF- 1 and $A F-2$ in the quantitative response to estradiol and tamoxifen. J Cell Sci 2010, 123(Pt 8):1253-1261. PMID: 20332105.

37. Dey S, Ghosh N, Saha D, Kesh K, Gupta A, Swarnakar S: Matrix metalloproteinase-1 (MMP-1) promoter polymorphisms are well linked with lower stomach tumor formation in eastern Indian population. PLOS One 2014, 5:9(2). PMID:24505369.

38. Liu D, Guo H, Li Y, Xu X, Yang K, Bai Y: Association between polymorphisms in the promoter regions of matrix metalloproteinases (MMPs) and risk of cancer metastasis: a meta-analysis. PLoS One 2012, 7(2):e31251. PMID: 22348060

39. Sun HB, Liu Y, Qian L, Yokota H: Model-based analysis of matrix metalloproteinase expression under mechanical shear. Ann Biomed Eng 2003, 31:171-180

40. Sun HB, Nalim R, Yokota $H$ : Expression and activities of matrix metalloproteinases under oscillatory shear in IL-1-stimulated synovial cells. Connect Tissue Res 2003, 44:42-49.

41. Sun HB, Yokota $\mathrm{H}$ : Altered mRNA level of matrix metalloproteinase-13 in MH7A synovial cells under mechanical loading and unloading. Bone 2001, 28(4):399-403.

42. Sun HB, Yokota H: Messenger-RNA expression of matrix metalloproteinases, tissue inhibitors of metallproteinases, and transcription factors in rheumatic synovial cells under mechanical stimuli. Bone 2000, 28(3):303-309.

43. Castillo AB, Triplett JW, Pavalko FM, Turner $\mathrm{CH}$ : Estrogen receptor- $\beta$ regulates mechanical signaling in primary osteoblasts. Am J Physiol Endocrinol Metab 2014, 306(8):E937-E944. PMID: 24619882.

44. Sasaki K, Takagi M, Konttinen YT, Sasaki A, Tamaki Y, Ogino T, Santavirta S, Salo J: Upregulation of matrix metalloproteinase (MMP)- 1 and its activator MMP-3 of human osteoblast by uniaxial cyclic stimulation. J Biomed Mater Res B Appl Biomater 2007, 80B:491-498. 
45. Yang J-H, Briggs WH, Libby $P$, Lee RT: Small mechanical strains selectively suppress matrix metalloproteinase-1 expression by human vascular smooth muscle cells. J Biol Chem 1998, 273(11):6550-6555.

46. Haga JH, Li Y-SJ, Chien S: Molecular basis of the effects of mechanical stretch on vascular smooth muscle cells. J Biomech 2007, 40:947-960.

47. Asundi KR, Rempel DM: Cyclic loading inhibits expression of MMP-3 but not MMP-1 in an in vitro rabbit flexor tendon model. Clinical Biomechanics 2008, 23:117-121.

48. Ushiyama T, Ueyama H, Inoue K, Ohkubo I, Hukuda S: Expression of genes for estrogen receptors alpha and beta in human articular chondrocytes. Osteoarthritis Cartilage 1999, 7(6):560-566. PMID: 10558854.

49. Nelson KK, Subbaram S, Connor KM, Dasgupta J, Ha XF, Meng TC, Tonks NK, Melendez JA: Redox-dependent matrix metalloproteinase-1 expression is regulated by JNK through Ets and AP-1 promoter motifs. J Biol Chem 2006, 281(20):14100-14110. PMID: 16569638.

50. Rutter JL, Benbow U, Coon Cl, Brinckerhoff CE: Cell-type specific regulation of human interstitial collagenase-1 gene expression by interleukin-1 $\beta$ (IL-1 $\beta$ ) in human fibroblasts and BC-8701 breast cancer cells. J Cell Biochem 1997, 66:322-336.

51. Philips A, Chalbos D, Rochefort H: Estradiol increases and anti-estrogens antagonize the growth factor-induced activator protein-1 activity in MCF7 breast cancer cells without affecting c-fos and c-jun synthesis. J Biol Chem 1993, 268(19):14103-14108.

52. Umayahara $Y$, Kawamori R, Watada H, Imano E, Iwama N, Morishima T, Yamasaki Y, Kajimoto Y, Kamada T: Estrogen regulation of the insulin-like growth factor I gene transcription involves an AP-1 enhancer. J Biol Chem 1994, 269(23):16433-16442.

53. Schultz JR, Petz LN, Nardulli AM: Cell- and ligand-specific regulation of promoters containing activator protein-1 and $\mathrm{Sp} 1$ sites by estrogen receptors $\alpha$ and $\beta$. J Biol Chem 2005, 280(1):347-354.

54. Mahajan A, Tandon V, Verman S, Sharma S: Osteoarthritis and menopause. J Indian Rheumatology Association 2005, 13:21-25.

55. Paech K, Webb P, Kuiper GGJM, Nilsson S, Gustafsson J-Å, Kushner PJ, Scanlan TS: Differential ligand activation of estrogen receptors ERa and ERß at AP1 sites. Science 1997, 277:1508-1510.

56. Giguère $V$, Tremblay A, Tremblay GB: Estrogen receptor $\beta$ : re-evaluation of estrogen and antiestrogen signaling. Steroids 1998, 63:335-339.

57. Kumar R, Zakharov MN, Khan SH, Miki R, Jang H, Toraldo G, Singh R, Bhasin $S$, Jasuja R: The dynamic structure of the estrogen receptor. J Amino Acids 2011,812540 .

doi:10.1186/s13293-014-0014-6

Cite this article as: Thaler et al:: Estrogen receptor beta and truncated variants enhance the expression of transfected MMP-1 promoter constructs in response to specific mechanical loading. Biology of Sex Differences 2014 5:14.

\section{Submit your next manuscript to BioMed Central and take full advantage of:}

- Convenient online submission

- Thorough peer review

- No space constraints or color figure charges

- Immediate publication on acceptance

- Inclusion in PubMed, CAS, Scopus and Google Scholar

- Research which is freely available for redistribution 